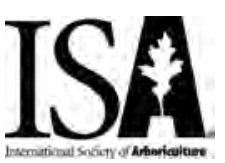

Arboriculture \& Urban Forestry 2016. 42(5): 301-317

\title{
Engaging Residents in Street Tree Stewardship: Results of a Tree Watering Outreach Intervention
}

\author{
Christine Moskell, Nina Bassuk, Shorna Allred, and Pat MacRae
}

\begin{abstract}
Street trees provide numerous environmental, community, and health benefits, but municipal urban forestry programs often lack the public resources to adequately maintain trees, particularly in the time immediately following planting. Watering trees in the first three years after planting is critical for tree survival. A quasi-experimental design was used to test whether an outreach intervention impacted residents' street tree watering behavior, and whether their watering behavior enhanced soil moisture, an important outcome for tree growth. Residents at mailing addresses for trees in the treatment group received educational materials about watering, while the control group received no educational materials. Soil moisture data was collected weekly at every tree throughout the growing season (May-September 2012) and used as a proxy for residents' watering behavior. Results indicate that the postcards had a positive impact on residents' watering behavior, but that the impact diminished over time. While the impact of the postcards on soil moisture was not statistically significant, the evaluation of the outreach intervention has practical significance for future educational efforts to engage residents in street tree watering.

Key Words. Community Engagement; Soil Moisture; Stewardship; Urban Trees.
\end{abstract}

Street trees can enhance the livability and sustainability of cities by providing a number of environmental, health, and community benefits, but the provision of these benefits is dependent upon street tree survival (Roman et al. 2014). Research shows that the first three years after a street tree is planted is a critical period for tree establishment and growth, yet it is also a time of stress for young trees (Trowbridge and Bassuk 2004). When trees are harvested at the nursery, approximately $90 \%$ of their fine nutrient and water absorbing roots may be damaged or removed (Whitlow and Bassuk 1988). After replanting, street trees can experience transplant shock, which is the reduction in water and nutrient uptake due to their damaged root systems. Transplant shock can inhibit tree growth and establishment, which is one reason why street tree mortality is very high in the first one to three years post-planting (Trowbridge and Bassuk 2004; Roman and Scatena 2011). Trees that do survive often need two to three years to recover from transplant shock and to resume normal growth (Trowbridge and Bassuk 2004).

Watering street trees in the first one to three years after they are planted can help them recover from transplant shock (Whitlow and Bassuk 1988). It is recommended that newly planted trees get 56.8-75.7 liters of water per week (Johnson et al. 2010). However, municipal urban forest managers may not be able to adequately water newly planted trees on a weekly basis due to a lack of public resources for post-planting tree maintenance (Pataki et al. 2011; Pincetl et al. 2013). People's efforts to water street trees are especially important, given the high levels of water stress that trees experience in urban environments that may not be remediated by natural rainfall (Whitlow et al. 1992; Ferrini and Fini 2011; Vico et al. 2014), especially in periods of drought and higher temperatures (Dale and Frank 2014). Practitioners of large-scale urban tree planting initiatives in cities across the United States have cited the inability to adequately water newly planted street trees as a major challenge to the success of these initiatives (Young 2011). For this reason, many cities and tree planting initiatives rely on residents, nonprofit organizations, and community groups to help maintain newly planted street trees (Young 2011; Pincetl et al. 2013; Young and McPherson 2013). 
The involvement of residents and volunteers in watering and otherwise stewarding street trees is beneficial for a number of reasons. First, community involvement may address the lack of government resources for tree watering. Surveys of public officials involved in municipal urban forest management have noted a lack of funding as a significant challenge (Grado et al. 2006; Driscoll et al. 2015). Thus, relying on the community to help water street trees may be many cities' most feasible economic and logistical option for ensuring trees are adequately watered. Second, community participation in urban forest management may result in the empowerment of residents. Individual-level empowerment is defined as the belief that one can make a positive difference, an understanding of the socio-political context, and taking action to address issues of concern to them (Zimmerman 2006). Empowerment has often been mentioned as a possible outcome of residents and volunteers' participation in community tree planting events (Sklar and Ames 1985; Sommer et al. 1994; Summit and Sommer 1998; Austin 2002; Elmendorf 2008). For example, tree-planting projects may enhance residents' sense of pride in their community and their feeling of self-efficacy related to improving their neighborhood (Dwyer et al. 1992; Bloniarz and Ryan 1996). Involving residents in the stewardship of street trees may also produce similar feelings of community pride and efficacy toward neighborhood improvement (Mincey and Vogt 2014). Lastly, community involvement in urban forest management may enhance the sustainability of urban forests (Clark et al. 1997; Kenney et al. 2011).

Recent studies suggest that residents' involvement in stewarding street trees may enhance tree growth and survival. A study in New York City, New York, U.S., found that signs of stewardship in the built environment surrounding street trees (e.g., planted flowers or mulch in the planting bed, evidence of weeding, and stewardship-related signage close to the tree) were significantly associated with higher survival rates ( $\mathrm{Lu}$ et al. 2010). Another New York City study found that street trees that were stewarded by local volunteers trained in tree watering, tree pit care, and tree health assessment had a significantly higher survival rate over five years than did trees that were not monitored by volunteers (Boyce 2010). Examining the rela- tionship between community tree planting groups and tree survival in New Haven, Connecticut, U.S., Jack-Scott et al. (2013) found that tree survival was significantly associated with increased years of group experience and with an alignment of tree plantings with group mission (e.g., park trees planted by "friends of parks" groups).

More recently, Mincey and Vogt (2014) investigated the relationship between tree survival and the street tree watering strategies employed by groups of neighbors in Indianapolis, Indiana, U.S. Using self-reported measures of watering behavior, Mincey and Vogt (2014) conducted semi-structured interviews to examine the presence or absence of collective watering strategies in each neighborhood. Collective watering strategies included signed agreements between neighbors, neighbors monitoring each other, and giving verbal reminders to encourage each other to water newly planted street trees. Street trees watered through collective watering strategies had higher survival rates than street trees watered by individual residents in the absence of agreements or reminders between neighbors. Collective watering strategies may have increased the sense of accountability between neighbors, which may have motivated residents to water their street trees more consistently, thereby enhancing the health of the trees (Mincey and Vogt 2014).

The recent studies on the impact of volunteer involvement in street tree stewardship on tree health and survival are limited. With the exception of $\mathrm{Lu}$ et al. (2010), these studies examined programs coordinated by a local non-profit organization rather than with residents who were not participants in such programs. While non-profit organizations play an important role in coordinating street tree stewardship efforts in the community (see Leff 2013), these organizations may not be present or active in every community where cities plant street trees, and those that are present may not have the capacity to coordinate residents' street tree watering on a regular basis across an entire city. Furthermore, many cities require residents and private property owners to maintain street trees planted in public rights-ofway adjacent to their property (Loukaitou-Sideris and Ehrenfeucht 2009). However, many residents' may not recognize themselves as responsible 
for caring for street trees planted. For example, a study conducted in New York City found that many residents believed the government was responsible for managing street trees on public property, rather than civil society organizations and community volunteers (Moskell and Allred 2013). Despite partnerships with nonprofit organizations that work to raise community awareness about the importance of street tree maintenance, community engagement in urban forest management remains a significant challenge for municipal urban tree planting initiatives across the U.S. (Young 2011; Pincetl et al. 2013; Campbell 2015).

Research is needed to examine the involvement of residents in street tree stewardship outside of formal volunteer programs hosted by nonprofit organizations, as many residents may not have access to, or a willingness to participate in, such programs. Furthermore, research needs to examine and evaluate strategies that city agencies can use, independent of local nonprofit organizations, to recruit residents to water street trees. For example, city agencies can use informational strategies to enhance residents' awareness of the importance of watering newly planted street trees. Informational strategies have been included in interventions to increase knowledge of an environmental problem so as to promote proenvironmental behavior to address that problem (Steg and Vlek 2009). An example of an informational strategy is prompting, or the use of reminders about when to complete a pro-environmental behavior (Lehman and Geller 2004). Prompts that are noticeable, self-explanatory, and presented in close proximity to where the behavior occurs may be most effective for encouraging behavior change (McKenzie-Mohr 2011). Prompts with strong visual cues that indicate the specific action to be completed, and that appear when the action needs to be completed, may be most effective at prompting a certain behavior (see Tetlow et al. 2014 for a review). Prompting has been an effective informational strategy in interventions to promote pro-environmental behaviors, such as energy conservation (see Steg and Vlek 2009 for a review). Prompts can be relatively low cost (Lehman and Geller 2004), which make them an attractive option for cities to use to encourage residents to water newly planted street trees.

\section{The Current Study}

The goal of this study was to evaluate the impact of an outreach intervention that used weekly postcard reminders to encourage residents to water newly planted street trees. To the authors' knowledge, no studies have examined tree-watering behavior at the individual tree level using both self-reported watering behavior and soil moisture measurements. This study uses both social and biophysical measures to identify evidence of watering by residents and whether watering occurred as a result of the outreach intervention. The purpose of taking soil moisture measurements was to "ground truth" or validate residents' self-reported watering behavior survey responses. Another contribution of this study is the use of a quasiexperimental design, which allowed researchers to isolate the effect of the outreach intervention (i.e., receiving a postcard reminder) on residents' watering behavior and soil moisture, while controlling for other variables that may affect soil moisture (e.g., soil compaction). Research questions and hypotheses $(\mathrm{H})$ for this study were as follows:

1. What is the effect of an outreach intervention on residents' watering behavior and soil moisture, controlling forsoil compaction and watering by the city?

- H1: Residents in the treatment group will water trees more frequently than residents in the control group, as indicated by self-report.

- H2: Trees in the treatment group will have higher average weekly soil moisture than trees planted at addresses in the control group.

- H3: Average weekly soil moisture will be greater between treatment and control groups in the weeks a postcard was mailed to residents.

2. Does self-reported watering behavior align with measures of soil moisture?

- H4:Treesthatwere reported tobewateredmore frequently will have a higher average weekly soil moisture than trees that were reported as watered less frequently by residents.

3. To what degree is direct communication with residents via postcard an effective strategy for ensuring newly planted street trees get watered? 


\section{METHODS}

\section{Study Site}

This study took place within a 17 -week period between May and September 2012 in Ithaca, New York, a small city in the Finger Lakes region of New York State. Ithaca's urban forest management goals and street tree watering challenges are similar to those found in other small cities across the United States. Despite the presence of a number of citizen groups involved in urban forest planning and advocacy in Ithaca, these groups do not take an active role in watering the street trees planted on public property throughout the city. In light of the Ithaca Parks and Forestry Division's goal to fill $100 \%$ of the available planting sites by 2015, watering newly planted street trees is an important concern in the city (Denig 2014). To facilitate watering, the Parks and Forestry Division installed a plastic irrigation bag (TreeGator, Spectrum Products, Inc., Raleigh, North Carolina, U.S.) to the trunk of each newly planted tree in early May 2012. The irrigation bags hold $\sim 56.8 \mathrm{~L}$ of water, which permeates into the ground around the tree trunk by way of small holes at the bottom of the bag. Staff from the Department of Public Works are responsible for filling up the bags with water. However, time constraints and additional commitments make it difficult for staff to adequately water each tree weekly. Thus, the Division relies upon residents to help water the street trees using the irrigation bags. However, the City has not previously had the resources for mass communication materials to inform residents that their help is needed to water trees (Denig 2014). The outreach intervention developed as part of the study (to be discussed herein) was designed to address this communication need.

\section{Study Sample}

This study includes both a biophysical sample and a social sample. The biophysical sample included all street trees $(\mathrm{N}=81)$ planted between autumn 2011 (53.1\%; $\mathrm{n}=43)$ and spring 2012 (46.9\%; $\mathrm{n}=38$ ) by the City of Ithaca's Parks and Forestry Division. Three species of trees were planted: amur maackia (Maackia amurensis Rupr. and Maxim) (30.9\%; $\mathrm{n}=25)$, swamp white oak (Quercus bicolor Wild) $(35.7 \% ; n=29)$, and Glenleven linden (Tilia cordata Mill 'Glenleven') (33.3\%; $\mathrm{n}=27)$. The city made all decisions about tree planting, such as species selection and planting locations. Before each tree was planted, each address received a letter from the City notifying them about the upcoming planting. After the tree was planted, the City left a door hanger at each residence informing them about the benefits trees provides. The social sample included the mailing addresses (including apartments and commercial offices) $(\mathrm{N}=114)$ that were listed at the address where each tree was planted.

\section{Study Design}

Using a nonequivalent control group design (specifically a posttest-only control group design) (Campbell and Stanley 1963; Kerlinger and Lee $2000)$, the mailing addresses $(\mathrm{N}=114)$ associated with the building directly adjacent to each tree were assigned into treatment and control groups. Tree species was the matching variable for assigning trees so that the treatment and control groups would have relatively equal numbers of each species (Shadish et al. 2002). It was later determined how many individual apartment or business units were listed at each address using a county tax assessment database. Most of the street trees were planted in front of a single-family home $(n=52)$ and thus were associated with one mailing address each. However, some trees $(n=20)$ were planted in front of a multi-family home, which explains why the total number of mailing addresses $(\mathrm{N}=114)$ was greater than the number of street trees planted $(\mathrm{N}=81)$. Trees were assigned to treatment or control at the building level. For example, if a tree was assigned to the treatment group, the mailing addresses for all of the individual apartment units listed at the adjacent building were each assigned to the treatment group.

\section{The Outreach Intervention}

The treatment group $(\mathrm{N}=66$ mailing addresses; $\mathrm{N}=47$ trees) received an outreach intervention that consisted of postcard reminders to water the tree (eight total) that were mailed bi-weekly over a 17 -week period. The postcards included a picture of a tree with an irrigation bag and instructed residents to fill the bag with water once per week. The control group $(\mathrm{N}=48$ mailing addresses; $\mathrm{N}=$ 34 trees) did not receive the outreach intervention. 


\section{Social Data Collection}

Residents' self-reported watering behavior was measured in two different surveys. First, the treatment group received surveys at the end of June, July, and August. Questionnaires asked how often they had watered their tree in the past month; the residents could fill in the exact number of times they had watered. The treatment group was not notified about these questionnaires ahead of their delivery. The control group did not receive these monthly questionnaires to avoid the suggestion that the control group's watering behavior was being monitored.

Second, mailing addresses in both the treatment and control groups $(\mathrm{N}=114)$ received a written survey at the end of the 2011-2012 growing season in November 2012. The survey asked residents about their watering behavior and also included a question directed to the treatment group to evaluate whether the postcards distributed as part of the outreach intervention were helpful for learning how, and being reminded, to water the tree. The back page of the survey included a space in which respondents' could write comments with additional information they wanted to share. Both the monthly surveys and the final survey were distributed using a modified version of the drop-off, pick-up method. One week prior to the delivery of a survey, all addresses in the treatment and control groups received a postcard notifying them of the upcoming survey. Surveys were dropped off the following week at mailboxes with return postage and a cover letter with instructions for mailing back the survey (Vaske 2008; Broussard Allred and Ross-Davis 2011).

\section{Biophysical Data Collection}

Two biophysical variables were measured at each tree. First, soil moisture measurements were taken at each tree using a ThetaProbe Soil Moisture Sensor (Delta-T Devices Ltd, Cambridge, UK) on the same day every week in 15 weeks within a 17-week period between May and September 2012. The probes measure the dielectric constant of soil to estimate the volumetric soil water content $\left(\mathrm{m}^{3} \mathrm{~m}^{-3}\right)$. Pure water is measured at $1.0 \mathrm{~m}^{3} \mathrm{~m}^{-3}$ and dry soil corresponds to a measurement of $0.0 \mathrm{~m}^{3} \mathrm{~m}^{-3}$ (Gaskin and Miller 1996). Each week at each tree, the average of three probe readings were recorded. Second, soil compaction (a proxy for site conditions) was measured using a penetrometer (Dickey John Soil Compaction Tester, Minneapolis, Minnesota, U.S.) in mid-September 2012 at each tree. At each tree, the average of three penetrometer readings was recorded. The unit of measurement for the penetrometer (inches) is interpreted as the inches of depth before reaching 300 pounds per square inch resistance. Because each tree was planted on public property, residents were not informed that soil moisture and soil compaction near their tree was being measured.

Average weekly pan-evaporation data for Ithaca, NY/Tompkins County was collected from the Northeast Regional Climate Center at Cornell University. Pan-evaporation integrates temperature and precipitation, thereby providing a measure of the time of trees' greatest need for water when there is more evaporation pressure on both the soil and plant leaves. The four weeks during the summer that the City's Department of Public Works' watering truck watered trees throughout the city was also recorded. The Department of Public Works was not notified of which street trees in this study were assigned to the treatment and control groups. In each of those four weeks, the city watered trees in only some neighborhoods. However, one limitation of this data was that individual tree watering data, such how much water was applied to each tree, was unavailable. It was assumed that the city watered all of the trees in each neighborhood, but it's likely the watering truck may have missed some trees. Limitations associated with this data are presented in the Discussion section.

\section{Data Analysis}

Data analysis procedures are organized in the following by the three research questions.

\section{Research question 1: Outreach intervention and self-reported watering behavior}

In order to determine the effect of the outreach intervention on residents' watering behavior (and subsequently on soil moisture), watering behavior was analyzed in two ways. First, descriptive frequencies were conducted to determine how many respondents to the monthly surveys (distributed to the treatment group) had watered their trees. The mean number of times that respondents had watered was also calculated from the monthly survey 
results. Second, descriptive frequencies were calculated to determine how many respondents to the final survey (distributed to both the treatment and control groups) had watered their trees. Chi-square tests were conducted to determine if the differences in self-reported watering (from the final survey) between the treatment and control groups were significant. Fisher's Exact Test results are reported in instancesin which there were cell counts $<5$. Onlyfinal survey respondents who lived at their address over summer 2012 were included in this second analysis.

To measure the impact of the outreach intervention on soil moisture, an independent samples t-test was conducted to identify significant differences in average soil moisture levels for the treatment and control groups. Means for both groups for 15 out of 17 weeks in which soil moisture was collected are reported (the data collection team was on vacation for two of the 17 weeks, hence soil moisture is only reported for 15 weeks).

To control for confounding variables not measured, a difference-in-difference regression analysis was conducted, which is an analytical tool used in social science research and program evaluation to measure the differences in two groups before and after a treatment. One strength of this analysis is that it accounts for underlying variation between treatment and control groups (Lechner 2011). Difference-in-difference analysis has been used in forestry to evaluate programs that pay producers of ecosystem services in developing countries (Pattanayak et al. 2010; Honey-Rosés et al. 2011; Arriagada et al. 2012). Difference-in-difference analysis has also been conducted in studies relevant to urban forestry that measured the interaction between household location decisions and urban green space (Stone et al. 2015), and also examined the impact of vacant lot greening programs on crime and human health (Branas et al. 2011).

In this study, the goal of the difference-in-difference regression analysis was to compare the difference in soil moisture between the treatment and control group in the week before a postcard was mailed to the difference in soil moisture between the treatment and control group in the week a postcard was mailed. The difference between these two differences can be interpreted as the impact of the postcard "treatment" on soil moisture. The difference-in-difference analysis was implemented using seven different multiple linear regression models, one each for postcards two through eight.

For the purposes of explaining the following regression model, week X represents the week prior to a postcard mailing, and week $\mathrm{Y}$ represents the week a postcard was received. Five independent variables were entered into the regression model to predict the dependent variable, soil moisture in week Y. First, a dummy variable week $(0=$ week $X, 1$ $=$ week $\mathrm{Y}$ ) was created to represent the difference in soil moisture between weeks $\mathrm{Y}$ and $\mathrm{X}$ for the control group. Second, a postcard received dummy variable $(0=$ no postcard received, $1=$ postcard received $)$ which represents the difference in soil moisture between the treatment and control groups in week $\mathrm{X}$. Third, a dummy variable, postcard-week, which indicates all of the trees planted at a residence that received a postcard in week $\mathrm{Y}$, the week the postcard was mailed $(0=$ no postcard received in week $\mathrm{Y}, 1$ = postcard received in week Y). The postcard-week variable represents the impact of the postcard, which can be understood with the following formula:

[1] Postcard impact $\left(\beta_{\text {postcard-week }}\right)=($ Treatment soil moisture in week $\mathrm{X}$ - Control soil moisture in week $X)$ - (Treatment soil moisture in week $Y$ - Control soil moisture in week $Y$ )

The fifth variable, soil compaction (continuous), represents the penetrometer measurements at each tree. A sixth independent dummy variable, city watering $(0=$ not watered, $1=$ watered $)$, was added in the model for postcards four through eight to capture the four weeks $(7,9,10,12)$ in which the city watered some of the trees. A city watering score of 1 indicates that the tree was located in a neighborhood where the city watered that week. The reader will be guided in how to interpret the beta coefficients for the regressions to determine the impact of the postcards in the Results section. It was impossible to control for additional biophysical factors (average weekly temperature, precipitation, and evaporative demand) that may also affect soil moisture, as the data collected for these variables were constant across all of the trees. However, the difference-in-difference analysis accounts for any pre-existing differences in these variables between treatment and control groups. The implications of this limitation for this study will be addressed in the Discussion section. 


\section{Research question 2: Self-reported watering behavior and soil moisture}

To determine which trees were watered and at what frequency, a dummy variable for watering score was computed based on watering behavior as selfreported on the final survey. It was only possible to compute water scores for the trees at addresses that completed the final survey and answered the question about watering behavior. Trees were coded as: $0=$ never watered, $1=$ watered a few times over the summer, $2=$ every other week, and $4=$ at least once per week. For trees planted outside of apartment buildings, there were no instances of more than one apartment at the same address reporting that they watered the tree. Pearson's correlation coefficients were calculated to determine the relationship between the watering score and soil moisture in each of the 15 weeks. Pearson's correlation coefficients were also calculated to determine the relationship between self-reported watering and soil moisture in the first and second halves of the summer. A oneway analysis of variance (ANOVA) was calculated for each of 15 weeks to identify significant differences in average weekly soil moisture between trees with different watering scores. Multiple comparisons were calculated using Bonferroni post hoc tests.

\section{Research question 3: Evaluation of the out- reach intervention}

To evaluate the effectiveness of the outreach intervention, descriptive frequencies were calculated to identify how many final survey respondents believed the postcards were helpful in learning about how to water the tree and in reminding them to water their tree. Cross-tabulations and $\chi^{2}$ analyses were conducted to examine how many treatment group respondents who had watered had found the postcards to be helpful reminders. Comments provided by final survey respondents on the back page of the questionnaire that related to watering, the postcards, or the project in general are also reported and used to evaluate the outreach intervention. Analyses for this research question only include final survey respondents who resided at their address in summer 2012.

\section{RESULTS}

First, descriptive statistics related to the characteristics of the trees, the monthly and final survey response rates, and the socio-demographics of survey respondents are presented. Subsequent results are presented and organized by research question.

\section{Descriptive Statistics}

Descriptive statistics for the site type and species of the street trees are found in Table 1. The majority of trees were planted at single-family homes (64.2\%). A Fisher's Exact Test found no significant difference in the distribution of trees across site types between the control and treatment groups $(P=0.31)$ or in the distribution of tree species between the control and treatment groups $(P=0.36)$. The city watered the street trees in four different weeks. More than half of all trees were watered in week $7(75.3 \%, \mathrm{n}=61)$, week $9(50.6 \%, \mathrm{n}=41)$, and week $12(93.8 \%, \mathrm{n}=76)$, but only a few trees were watered in week $10(7.4 \%$, $n=6)$. The percentage of treatment group trees that were watered in each of those weeks were $54.1 \%$ in

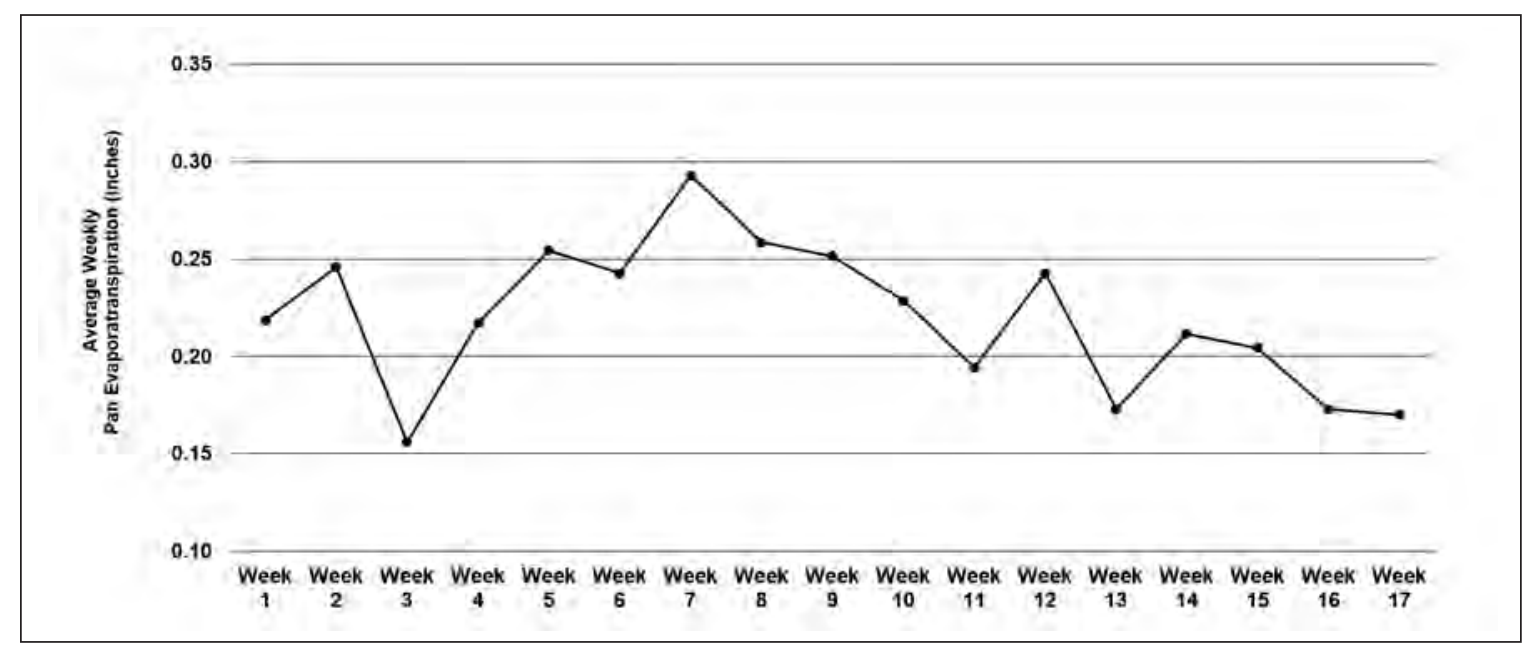

Figure 1. Average weekly pan-evaporation for Ithaca, NY/Tompkins County (23 May - 12 September 2012). 
week $7,56.1 \%$ in week $9,83.3 \%$ in week 10 , and $55.3 \%$ in week 12 . Chi-square analyses and Fisher's Exact Tests revealed no significant difference in city watering between the treatment and control group.

Mean soil compaction for the 81 trees was 10.004 inches (standard deviation $=3.865$ ). There was no significant difference in soil compaction between the treatment group [9.34 inches $(23.72 \mathrm{~cm})]$ and the control group [10.48 inches $(26.62 \mathrm{~cm})](\mathrm{t}=-1.315$, $\mathrm{df}=79, P=0.192)$. For the 17 week period in which this study took place, the daily average precipitation was 0.07 inches $(0.18 \mathrm{~cm})$ (standard deviation: 0.17 ), the average daily temperature was $20.33^{\circ} \mathrm{C}$ (standard deviation: 6.8), and the average daily pan evaporation rate was 0.22 inches $(0.56 \mathrm{~cm})$ (standard deviation 0.06). Average weekly pan evaporation rates for the study period are presented in Figure 1.

\section{Survey response rates}

The response rate for the monthly watering survey (distributed to the treatment group only) was highest in June $(21.5 \%, \mathrm{n}=14)$, but decreased in July $(18.5 \% ; \mathrm{n}=12)$ and August $(15.4 \%, \mathrm{n}=10)$. The response rate for the final survey was $39.5 \%$ $(\mathrm{n}=45)$. A Fisher's Exact Test found no significant differences in the final survey response rate between the treatment and control group $(P=0.52)$.

While a formal survey non-response followup was not conducted, non-response bias was checked by comparing survey response rate by building type. A Fisher's Exact Test revealed differences in survey response and building type $(P$ $=0.085)$. The majority of respondents resided at single-family homes $(60 \%, \mathrm{n}=27)$, whereas the majority of non-respondents $(57.1 \%, \mathrm{n}=36)$ and refusals $(66.7 \%, \mathrm{n}=4)$ resided at apartment buildings.

\section{Socio-demographics of final survey respon- dents}

The majority of respondents to the final survey were homeowners $(76.3 \%, \mathrm{n}=29)$, aged $55+(51.4 \%, \mathrm{n}$ = 19), non-Hispanic/Latino (97.1\%, $\mathrm{n}=34$ ), Caucasian $(85.7 \%, \mathrm{n}=30)$, and have an earned income of greater than USD $\$ 50,000(68.8 \%, \mathrm{n}=22)$. There were no significant differences in homeownership $\left(X^{2}=0.474, P=0.491\right)$, ethnicity $\left(\chi^{2}=1.328, \mathrm{p}=0.249\right)$, race $\left(\chi^{2}=0.628, P=0.428\right)$, or income $\left(\chi^{2}=0.121, P=0.728\right)$ between final survey respondents in the treatment and control groups. A Fisher's Exact Test showed no significant age differences between final survey respondents in the treatment and control groups $(P=0.35)$.

\section{Research Question 1: Outreach Inter- vention and Self-Reported Watering Behavior}

The majority of respondents to the monthly surveys (treatment group only) reported watering their trees in June $(78.6 \%, \mathrm{n}=11)$, July $(72.7 \%, \mathrm{n}=8)$, and August $(60 \%, n=6)$. On average, respondents

Table 1. Distribution of trees across site types and distribution of tree species for the treatment and control groups. Crosstabulations for the control and treatment groups present row percentages of total $\mathrm{N}$.

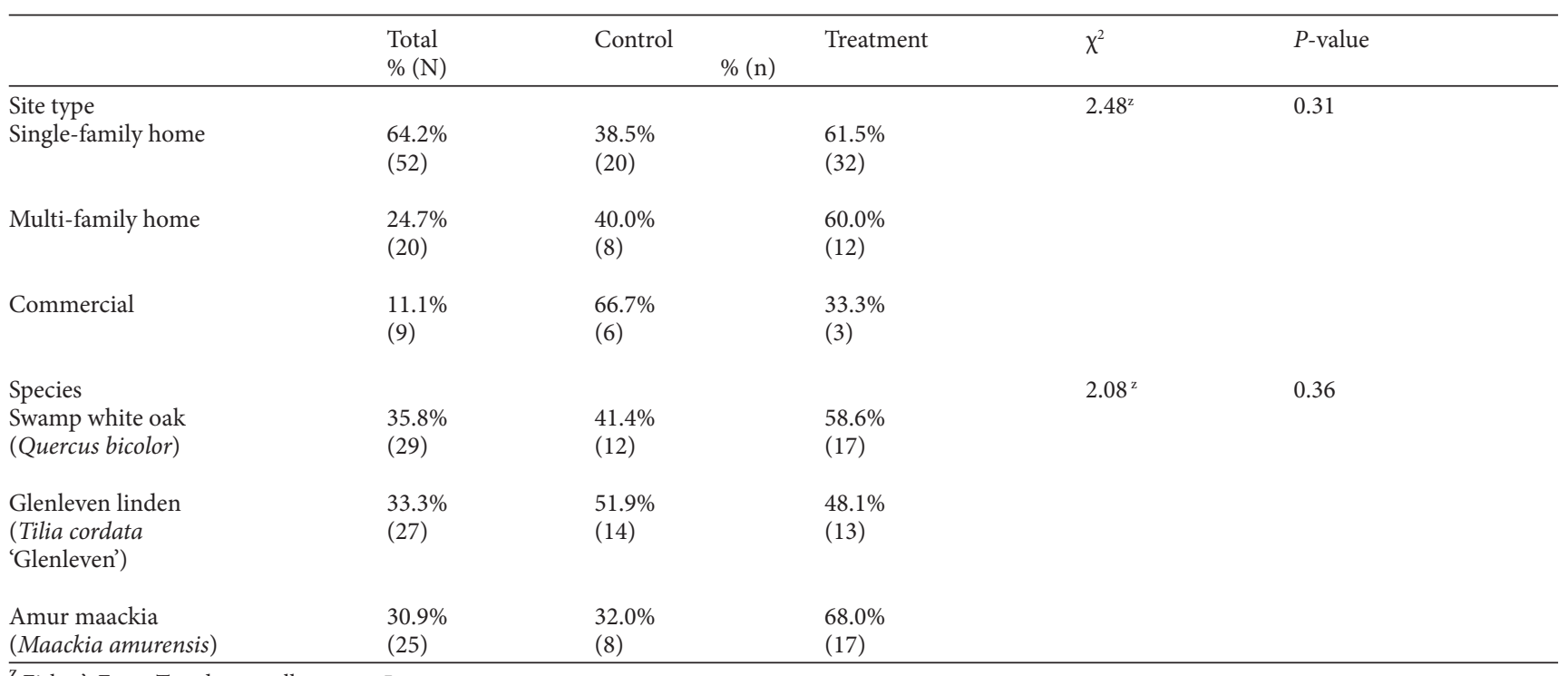

${ }^{\mathrm{z}}$ Fisher's Exact Test due to cell counts $<5$. 
watered 3.82 times in June, 4.56 times in July, and 4.17 times in August. After removing four respondents $(9.5 \%)$ who reported they had not lived at their address during summer 2012, the majority of final survey respondents $(35.3 \%, \mathrm{n}=12)$ reported watering their tree once per week, $11.8 \%(\mathrm{n}=4)$ reported watering bi-weekly, 20.6\% $(\mathrm{n}=11)$ reported watering a few times over the summer, and $32.4 \%(\mathrm{n}=34)$ reported never watering (Table 2). While the majority of respondents who had watered once per week were in the treatment group $(83.3 \%, \mathrm{n}=10)$, a Fisher's Exact Test found no sig- nificant differences in self-reported watering between the treatment and control groups $(P=0.816)$.

A statistically significant difference in average weekly soil moisture was observed between the control and treatment groups in week eight $(\mathrm{t}=-2.087$, $\mathrm{df}=77, P=0.04)$, with the treatment group having higher soil moisture than the control group. This same trend was found in week two $(\mathrm{t}=-1.912, \mathrm{df}=76, P=$ $0.06)$ and week six $(\mathrm{t}=-1.807, \mathrm{df}=78, P=0.08)$, but the differences between the groups were not statistically significant (Figure 2). The differences observed in week six and week eight fell within a period of

Table 2. Self-reported watering behavior from the final survey for the control and treatment groups.

\begin{tabular}{|c|c|c|c|c|}
\hline & \multicolumn{2}{|c|}{ Control } & \multicolumn{2}{|c|}{ Treatment } \\
\hline & $\%$ & (n) & $\%$ & (n) \\
\hline Once per week & $16.7 \%$ & $(2)$ & $83.3 \%$ & (10) \\
\hline Every other week & $25.0 \%$ & $(1)$ & $75.0 \%$ & (3) \\
\hline A few times over the summer & $28.6 \%$ & $(2)$ & $71.4 \%$ & (5) \\
\hline Never & $36.4 \%$ & $(4)$ & $63.6 \%$ & (7) \\
\hline
\end{tabular}

Note: Fisher's Exact Test $=1.419, P=0.816$.

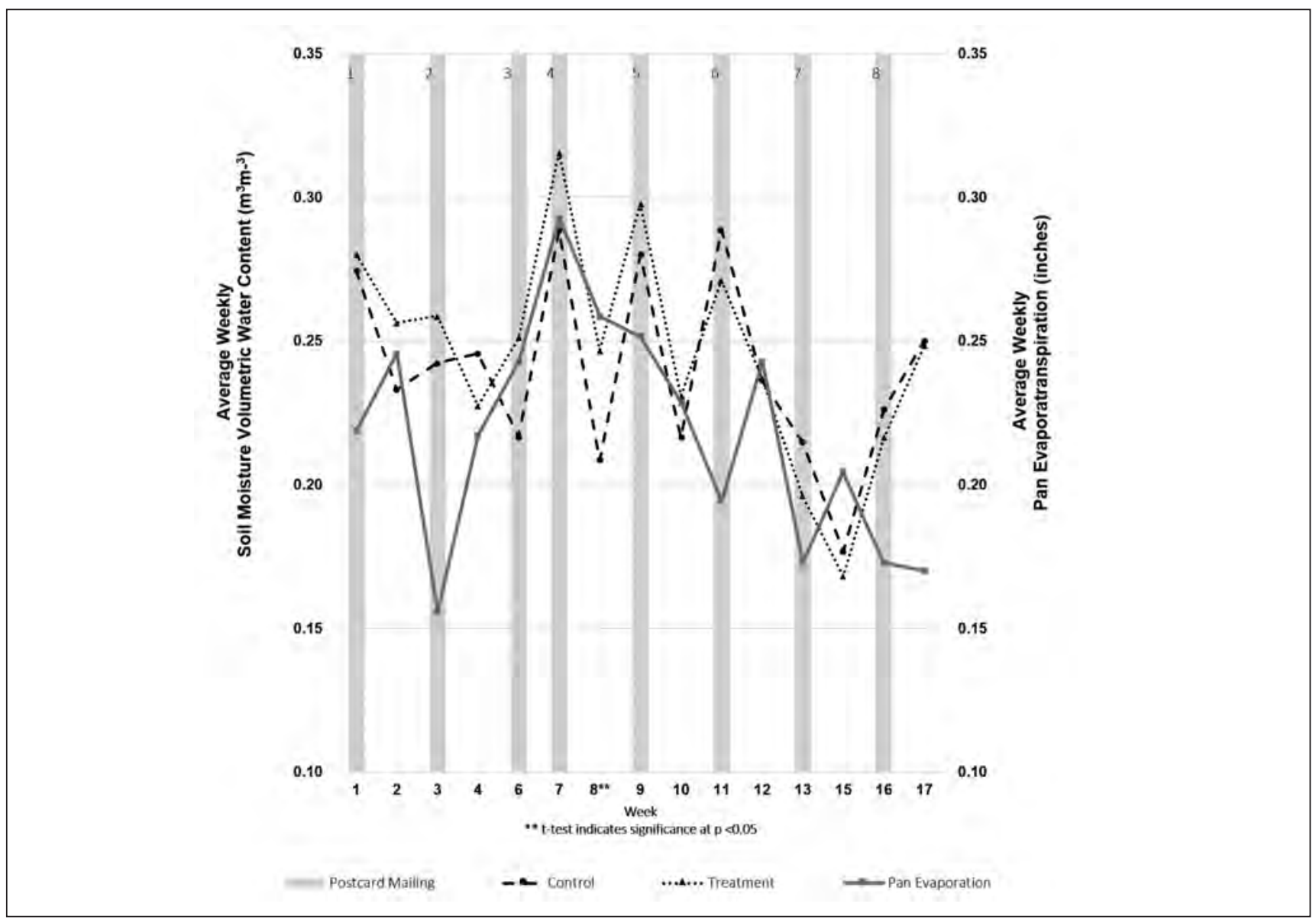

Figure 2. Average weekly soil moisture for trees in the treatment and control groups. 
high pan-evaporation, which corresponds to the time when trees had their greatest watering need.

After controlling for soil compaction and watering by the city, only two out of seven postcards had a statistically significant impact on soil moisture (Table 3). Regression model two indicated that postcard three had a significant impact on soil moisture in week six $\left(\beta_{\text {postcard-week }}=0.05 P=0.02\right)$, but note that the model's predictive power was weak (Adj. $\left.\mathrm{R}^{2}=0.02, \mathrm{~F}=1.88\right)$. The impact of postcard three (the coefficient for $\left(\beta_{\text {postcard-week }}\right)$ can be interpreted by looking at Figure 2 . In week four, the treatment group had lower soil moisture $\left(0.23 \mathrm{~m}^{3} \mathrm{~m}^{-3}\right)$ than the control group $\left(0.25 \mathrm{~m}^{3} \mathrm{~m}^{-3}\right)\left(\beta_{\text {postcard received }}=-0.02, P\right.$ $=0.21)$. The control group's soil moisture decreased from week four $\left(0.25 \mathrm{~m}^{3} \mathrm{~m}^{-3}\right)$ to week six $\left(0.22 \mathrm{~m}^{3} \mathrm{~m}^{-3}\right)$ $\left(\beta_{\text {week }}=-0.03\right)$. However, the treatment group's soil moisture increased from week four $\left(0.23 \mathrm{~m}^{3} \mathrm{~m}^{-3}\right)$ to week six $\left(0.25 \mathrm{~m}^{3} \mathrm{~m}^{-3}\right)$ when they received the postcard. Thus, there was a greater difference in soil moisture between the treatment and control group in week six $\left(0.03 \mathrm{~m}^{3} \mathrm{~m}^{-3}\right)$ than in week four $\left(-0.02 \mathrm{~m}^{3} \mathrm{~m}^{-3}\right)$, hence it can be concluded that postcard three had a significant impact on soil moisture in week six $\left(\beta_{\text {postcard-week }}=0.05 P=0.02\right)$. Regression model three showed that postcard four also had a significant impact on soil moisture in week seven $\left(\beta_{\text {postcard-week }}=0.05 P=0.04\right)$; this model had the strongest predictive power of any of the regression models (Adj. $\mathrm{R}^{2}=0.21, \mathrm{~F}=9.84$ ). In summary, five out of seven postcards had no statistically significant impact on soil moisture, with postcards two, five, six, and seven having a negative impact on soil moisture ( $\beta_{\text {postcard-week }}$ ranging from -0.05 to -0.01 ), and postcard eight having no impact. However, postcards three and four were mailed during the period of trees' greatest watering need, as indicated by high pan-evaporation rates at that time.

Table 3. Beta coefficients ( $P$-values in parentheses) for multiple linear regression models predicting the impact of each postcard mailing on average weekly soil moisture, controlling for soil compaction and city watering. All regression models include the week prior to the postcard mailing and the week in which the postcard was mailed.

\begin{tabular}{|c|c|c|c|c|c|c|c|}
\hline Regression model & 1 & 2 & 3 & 4 & 5 & 6 & 7 \\
\hline Postcard & 2 & 3 & $4^{z}$ & 5 & 6 & 7 & 8 \\
\hline Weeks & $2,3^{y}$ & $4,6^{y}$ & $4,7^{y x}$ & $8,9^{y x}$ & $10^{x}, 11^{y}$ & $12 \mathrm{w}, 13^{\mathrm{y}}$ & $15,16^{y}$ \\
\hline 1. Constant & $\begin{array}{l}0.21 \\
(0.00) \\
* * *\end{array}$ & $\begin{array}{l}0.23 \\
(0.00) \\
* * *\end{array}$ & $\begin{array}{l}0.23 \\
(0.00) \\
* * *\end{array}$ & $\begin{array}{l}0.16 \\
(0.00) \\
\star * \star\end{array}$ & $\begin{array}{l}0.20 \\
(0.00) \\
* * *\end{array}$ & $\begin{array}{l}0.25 \\
(0.00) \\
\star * *\end{array}$ & $\begin{array}{l}0.16 \\
(0.00) \\
\star * *\end{array}$ \\
\hline 2. Week & $\begin{array}{l}0.01 \\
(0.51)\end{array}$ & $\begin{array}{l}-0.03 \\
(0.10)\end{array}$ & $\begin{array}{l}0.04 \\
(0.01) \\
* * *\end{array}$ & $\begin{array}{l}0.07 \\
(0.00) \\
* * *\end{array}$ & $\begin{array}{l}0.07 \\
(0.00) \\
* * *\end{array}$ & $\begin{array}{l}-0.02 \\
(0.27)\end{array}$ & $\begin{array}{l}0.05 \\
(0.01) \\
* * *\end{array}$ \\
\hline 3. Postcard received & $\begin{array}{l}0.02 \\
(0.14)\end{array}$ & $\begin{array}{l}-0.02 \\
(0.21)\end{array}$ & $\begin{array}{l}-0.02 \\
(0.24)\end{array}$ & $\begin{array}{l}0.03 \\
(0.11)\end{array}$ & $\begin{array}{l}0.01 \\
(0.47)\end{array}$ & $\begin{array}{l}0.00 \\
(0.92)\end{array}$ & $\begin{array}{l}-0.01 \\
(0.50)\end{array}$ \\
\hline 4. Postcard-week & $\begin{array}{l}-0.01 \\
(0.70)\end{array}$ & $\begin{array}{l}0.05 \\
(0.02) \\
* *\end{array}$ & $\begin{array}{l}0.05 \\
(0.04) \\
* *\end{array}$ & $\begin{array}{l}-0.02 \\
(0.46)\end{array}$ & $\begin{array}{l}-0.03 \\
(0.22)\end{array}$ & $\begin{array}{l}-0.02 \\
(0.45)\end{array}$ & $\begin{array}{l}0.00 \\
(0.96)\end{array}$ \\
\hline 5. Soil compaction & $\begin{array}{l}0.003 \\
(0.03) \\
* *\end{array}$ & $\begin{array}{l}0.002 \\
(0.18)\end{array}$ & $\begin{array}{l}0.001 \\
(0.42)\end{array}$ & $\begin{array}{l}0.005 \\
(0.01) \\
* * *\end{array}$ & $\begin{array}{l}0.002 \\
(0.27)\end{array}$ & $\begin{array}{l}0.000 \\
(0.83)\end{array}$ & $\begin{array}{l}0.002 \\
(0.18)\end{array}$ \\
\hline 6. City watering & -- & -- & $\begin{array}{l}0.01 \\
(0.53)\end{array}$ & $\begin{array}{l}0.01 \\
(0.44)\end{array}$ & $\begin{array}{l}-0.02 \\
(0.46)\end{array}$ & $\begin{array}{l}-0.02 \\
(0.44)\end{array}$ & -- \\
\hline $\begin{array}{l}\mathrm{N} \\
\mathrm{R} \\
\mathrm{R}^{2} \\
\text { Adj. } \mathrm{R}^{2} \\
\mathrm{~F} \\
P \text {-value }\end{array}$ & $\begin{array}{l}158 \\
0.24 \\
0.06 \\
0.03 \\
2.24 \\
0.07 \\
\star\end{array}$ & $\begin{array}{l}161 \\
0.22 \\
0.05 \\
0.02 \\
1.88 \\
0.12\end{array}$ & $\begin{array}{l}162 \\
0.48 \\
0.23 \\
0.21 \\
9.41 \\
0.00 \\
\star \star \star *\end{array}$ & $\begin{array}{l}157 \\
0.41 \\
0.17 \\
0.14 \\
6.02 \\
0.00 \\
* * *\end{array}$ & $\begin{array}{l}162 \\
0.34 \\
0.12 \\
0.09 \\
4.08 \\
0.00 \\
* * *\end{array}$ & $\begin{array}{l}162 \\
0.23 \\
0.05 \\
0.02 \\
1.72 \\
0.13\end{array}$ & $\begin{array}{l}162 \\
0.34 \\
0.12 \\
0.09 \\
5.12 \\
0.00 \\
\star * \star\end{array}$ \\
\hline
\end{tabular}

\footnotetext{
${ }^{z}$ This regression model included week seven (when the postcard was mailed) and week four, the last previous week in which a postcard had not been mailed.

$y$ Indicates the week the postcard was mailed and the week dummy variable that was entered into the regression model.

${ }^{x}$ Indicates the week in which some of the trees were watered by the city.

Note: Double asterisk ${ }^{* *}$ ) indicates $P<0.05$; triple asterisk ${ }^{* * *}$ ) indicates $P<0.01$.
} 


\section{Research Question 2: Self-Reported Watering Behavior and Soil Moisture}

Watering scores were computed for 37 trees (45.7\%), based on the number of final survey respondents who answered the question about watering behavior ( $\mathrm{n}=37, \mathrm{~N}=44)$. The majority of trees $(35.0 \%, \mathrm{n}=13)$ were scored as never watered, $10.8 \%(\mathrm{n}=4)$ were watered biweekly, $18.9 \%(\mathrm{n}=$ 7 ) were watered a few times during the summer, and $35.1 \%(\mathrm{n}=13)$ were never watered. Trees that were watered weekly had the highest soil moisture in four out of 15 weeks (weeks 2, 7, 13, and 16), while trees that were watered biweekly had the highest soil moisture in 5 out of 15 weeks (9, 11, 12, 15, and 17) (Figure 3). However, ANOVAs revealed that there were only significant differences in soil moisture between the four groups of trees in week $11[F(3,33)=4.075, P=0.01]$ and week $13[F(3,33)=2.827, P=0.05]$. In week 11 , trees that had been watered weekly $\left(0.3 \mathrm{~m}^{3} \mathrm{~m}^{-3}\right)$ and biweekly $\left(0.33 \mathrm{~m}^{3} \mathrm{~m}^{-3}\right)$ both had significantly higher soil moisture than trees that had been watered only a few times over the summer $\left(0.21 \mathrm{~m}^{3} \mathrm{~m}^{-3}\right.$; $P \leq 0.05)$. Trees that had been watered only a few times over the summer had significantly higher soil moisture that trees that had never been watered $\left(0.30 \mathrm{~m}^{3} \mathrm{~m}^{-3} ; P=0.04\right)$. In week 13 , trees that had been watered weekly $\left(0.26 \mathrm{~m}^{3} \mathrm{~m}^{-3}\right)$ had significant higher soil moisture than trees that had been watered only a few times over the summer $(0.14$ $\left.\mathrm{m}^{3} \mathrm{~m}^{-3} ; P=0.04\right)$. These differences did not correspond to the period of trees' greatest watering need as evidenced by the pan-evaporation data.

There was a positive significant correlation between watering score and soil moisture in week two $(\mathrm{r}=0.36, P=0.03)$. However, there was no statistically significant correlation between watering score and soil moisture in all other weeks. Watering score was not correlated with soil moisture in the first half of the summer $(\mathrm{r}=0.25, P=0.12)$ or in the second half or the summer $(\mathrm{r}=0.06, P=0.7)$.

\section{Research Question 3: Evaluation of the Outreach Intervention}

There were 45 respondents to the final survey $(\mathrm{N}=114,39.5 \%$ response rate). Among the 20 respondents who remembered receiving postcards over the summer, the majority $(75 \%, \mathrm{n}=$ 15) believed the postcards were helpful to them in learning about how to water the new trees. A majority $(64.7 \%, \mathrm{n}=11)$ also believed the postcards were helpful reminders for watering. Respondents who had watered and not watered significantly differed in their memory of receiving postcards (Fisher's Exact Test $=5.87, P=0.03$ ). The majority of respondents who watered their tree $(76.2 \%, \mathrm{n}$ =16) did remember receiving a postcard, while the majority of respondents who never watered their tree $(66.7 \%, \mathrm{n}=8)$ reported never receiving a postcard. Of respondents who had watered and remembered receiving a postcard, the majority $(80 \%, \mathrm{n}=15)$ believed the postcards were helpful in learning how to water their tree, and $76.9 \%$ $(\mathrm{n}=10)$ believed the postcards were helpful watering reminders. There were also some respondents who didn't remember seeing the postcards $(23.8 \%, \mathrm{n}=5)$, but who still watered their tree.

Thirty respondents (24.6\%) wrote a comment on the back of the survey, and nine of these respondents (30\%) addressed watering, the postcards, or the project in general. Four comments addressed watering, with all but one coming from residents in the treatment group. The first person reported that she was unable to water because she did not have a large bucket with which to carry water to the tree. They thought that this project should have provided a large bucket to residents. A second person reported that she and her husband watered their tree when they watered their flowerbeds because even though they are elderly, they "still try to keep [their] home looking nice for the neighborhood." The third person who commented on watering reported that they had often forgotten to water the tree, but that they had always intended to water it. The only person to comment about watering in the control group reported that they had seen their tree being watered by the city, but started watering the tree themselves when their friend informed the commenter that they were involved in this study. It was assumed that their friend was in the treatment group, but it's important to note that the treatment group was never informed that they were part of a research study. Study limitations associated with this respondent's comment are acknowledged in the Discussion section.

One respondent in the treatment group reported that there were way too many postcards 


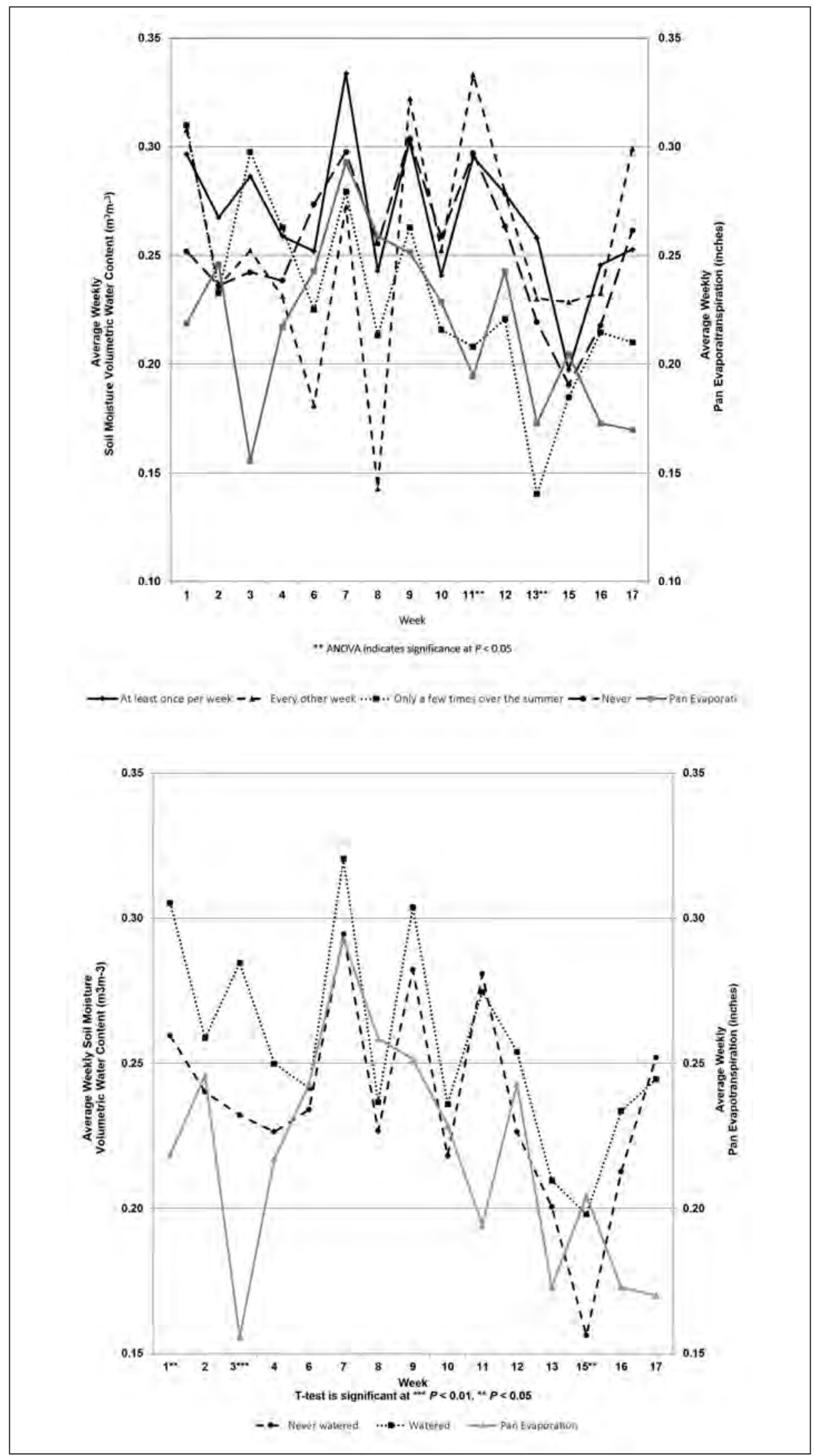

Figure 3. Average weekly soil moisture for trees that were watered and not watered as measured by self-report in surveys. 
about the tree and that they "found it extremely annoying." Finally, two respondents (both from the treatment group) expressed gratitude for the project in general. One respondent specifically thanked the project team, while the second respondent thanked "whoever took care of the tree."

\section{DISCUSSION}

These findings suggest that the outreach intervention may have had a very small impact on residents' watering behavior. While differences in self-reported watering between the treatment and control group were not statistically significant (therefore not supporting Hypothesis 1), differences in average weekly soil moisture were found between the two groups (supporting Hypothesis 2). After controlling for other variables that may impact soil moisture, the multiple linear regressions showed that postcards three and four had the greatest impact on soil moisture, which partially supported Hypothesis 3. These postcards were mailed when trees had their greatest watering need, as evidenced by a period of high pan-evaporation rates between weeks 6 and 10 . Thus, the fact that these postcards had the most impact on soil moisture during this time period likely also had the greatest impact on the health of the trees. However, the regression models for postcards three and four only predicted between $2 \%-21 \%$ of the variance in soil moisture, meaning the exact impact of the postcards on soil moisture cannot be determined with confidence. A larger sample size of trees would have enhanced the predictive power of the regression analyses. Lastly, researchers found that there were significant differences in soil moisture between trees that were reported as watered more frequently in only two out of the 15 weeks, thereby partially supporting Hypothesis 4. There was no statistically significant correlation between self-reported watering score and soil moisture. Additional research is needed to determine whether self-reported watering aligns with soil moisture. Future research should measure watering behavior on a weekly basis to determine if it is indicative of weekly soil moisture levels.

The results suggest that it took some time for the postcard mailings to effectively encourage watering behavior because an impact of the postcard was not observed until week six. It is likely that it may have taken residents some time to read the postcards and to realize that they were responsible for watering their tree. Figure 2 shows that there were greater differences in soil moisture between the treatment and control group in the first half of the summer, with the treatment group having higher soil moisture levels than the control group until week 11. This trend suggests that the impact of the postcard may have diminished over time, as there were no significant soil moisture differences between the two groups in the latter part of the summer. During that later period, the control group had higher soil moisture than the treatment group. The final survey respondent who wrote to us that the postcards were "annoying" further suggests that the postcards became less effective over time, perhaps because the postcards became repetitive. Although the statistical results suggest the outreach intervention did not impact watering behavior, the monthly survey results suggest that at least some residents in the treatment group had been watering their trees at the weekly frequency as recommended by the outreach intervention.

This study aimed to use soil moisture data as a way to "ground truth" or validate residents' selfreported watering behavior from written social surveys. However, there were only two weeks in which more frequently watered trees (weekly or biweekly) had significantly higher soil moisture levels than less frequently watered trees. This result is not surprising, given that self-reported watering was not significantly correlated with weekly soil moisture (except in week two), or with soil moisture in the first and second halves of the summer. Future research is needed to determine whether people's self-reported watering behavior can be validated with soil moisture data. The current study could be improved by having weekly measurements of self-reported watering behavior rather than the one retrospective measurement of watering behavior that was included on the final survey. Ground-truthing residents' self-reported watering behavior would also require controlling for other biophysical factors that may impact soil moisture at each site, such as weekly precipitation.

This study has practical significance for the design of future outreach interventions to encourage residents to water street trees. The strategy of mailing postcards may be most effective if 
they are delivered immediately prior to when trees' watering need is expected to be greatest. This would allow residents time to see and read the postcards before the trees are in most need of being watered. Based on the evaluation of the outreach intervention from the final survey, the use of postcards were effective in helping many residents learn how to water the tree, even though it may have taken them some time to read the materials sent. However, it is not clear that the postcards influenced watering behavior. One comment from the final survey suggested that the postcard did not turn their intention to water into actual watering behavior. One barrier faced by residents in the study may have been the lack of access to water, as was mentioned in one final survey comment. The outreach intervention was unable to address this issue, making the message on the postcards to water the tree ineffective for people who did not have an easy way to water the tree. Future outreach interventions should consider providing buckets or hoses to residents who do not have a way to carry water to their tree.

Another final survey comment suggested an additional way the outreach intervention could be improved. One respondent reported from the control group that the project raised their awareness that the city needed residents help to water street trees. However, their comment mentioned it was their friend who informed them of the project, rather than solely the postcards. This suggests that the outreach intervention "treatment" may have spilled over into the control group. The potential spillover may have biased some residents to water their trees as a result of them knowing they were being studied. It is important to note that residents in both the treatment and control groups were never informed that the research team was taking soil moisture measurements at each tree. However, it is possible that the treatment group may have deduced from the monthly watering surveys that their watering behavior was being monitored. Thus, the monthly surveys could have biased the treatment group, which may have weakened the internal validity of the study.

While spillover of a treatment is undesirable from a research design perspective, it is a positive outcome from an education and outreach perspective because it may have led to more people becoming aware of the city's tree water- ing needs. Perhaps the efficacy of the outreach intervention could have been improved if it also included a social component. Recent research has suggested that formal written agreements and monitoring between neighbors may be an effective way to encourage residents to water street trees (Mincey and Vogt 2014). Encouraging neighbors to personally remind each other to water street trees may be more effective than the relatively impersonal postcard reminders distributed in the outreach intervention.

\section{Study Limitations}

This study faced four limitations. The first limitation was the small samples of 81 trees and 114 mailing addresses. Limited survey response rates also prevented an accurate report of watering behavior at all trees. These small samples prohibited researchers from conducting more advanced analyses of soil moisture and watering behavior, as low statistical power prevented researchers from including additional biophysical variables that may impact soil moisture to the regression model. The second limitation was that researchers only had access to the countywide measures of precipitation, temperature, and pan evaporation, which meant these measures were equal across all of the trees in the study. The lack of variation in this biophysical data prevented researchers from entering this data as additional independent variables in the regression models; these variables would have been considered constants and dropped from the models. Future research should collect precipitation, temperature, and pan-evaporation data at each tree when weekly soil moisture measurements are collected. A third limitation was that the city watering data did not reflect whether each individual tree was watered, or with how much water. Individual tree watering data, including the quantities of water applied to each tree every week, would provide a more accurate account of other sources of water that may impact soil moisture levels at each tree. The fourth limitation was that some members of the treatment group may have known they were being studied due to the monthly surveys asking them about their watering behavior. These surveys may have biased them to water their trees more than they would have otherwise. Future research can 
reduce the effect of testing on internal validity by also administering the monthly surveys to the control group so that all participants in the study experienced the same "tests" of watering behavior.

\section{CONCLUSION}

This study suggests that postcard reminders mailed weekly may be an effective way for municipal urban forestry programs to remind residents to water street trees using irrigation bags. However, it may take a few weeks for the postcards to have a significant impact, and that impact may diminish over time if the postcards become repetitive or if residents become irritated by the number of mailings. Managers and practitioners interested in replicating the outreach intervention featured in this study should expand the intervention to ensure that residents have a source of water near the trees that need to be watered, such as by providing hoses or buckets. Ensuring that residents have a way to water newly planted street trees may enhance the effectiveness of postcard reminders to water. Future outreach interventions can also include a social component to encourage residents to remind each other to water their trees. Researchers interested in isolating the impact of an outreach intervention on street tree watering behavior should conduct the study with a larger sample of trees and mailing addresses in order to have the statistical power necessary to determine the impact of the outreach intervention on participants' behavior.

Acknowledgments. This publication was supported by a Science to Achieve Results (STAR) Fellowship Assistance Agreement number 91746101 awarded by the Environmental Protection Agency (EPA). It has not been formally reviewed by the EPA. The views expressed in this publication are solely those of the authors, and the EPA does not endorse any products or commercial services mentioned in this publication. The Toward Sustainability Foundation provided additional funding. Thanks to Delia Bolster and Diane Luebs at Cornell University for assistance with data collection and data analysis. Also thanks to the Human Dimensions Research Unit (Department of Natural Resources) at Cornell University for reviewing previous versions of this manuscript.

\section{LITERATURE CITED}

Arriagada, R.A., P.J. Ferraro, E.O. Sills, S.K. Pattanayak, and S. Cordero-Sancho. 2012. Do payments for environmental services affect forest cover? A farm-level evaluation from Costa Rica. Land Economics 88(2):382-399.

Austin, M.E. 2002. Partnership opportunities in neighborhood tree planting initiatives: Building from local knowledge. Journal of Arboriculture 28(4):178-186.
Bloniarz, D.V., and H.D.P. Ryan. 1996. The use of volunteer initiatives in conducting urban forest resource inventories. Journal of Arboriculture 22(2):75-82.

Boyce, S.E. 2010. It takes a stewardship village: Is community-based urban tree stewardship effective? Cities and the Environment 3(1):Article 3. <http://digitalcommons.lmu.edu/cate/vol3/iss1/3>

Branas, C.C., R.A. Cheney, J.M. MacDonald, V.W. Tam, T.D. Jackson, and T.R Ten Have. 2011. A difference-in-differences analysis of health, safety, and greening vacant urban space. American Journal of Epidemiology 174 (11):1296-306.

Broussard Allred, S.B., and A.L. Ross-Davis. 2011. The drop-off pick-up method: An approach to reduce nonresponse bias in surveys. Small-scale Forestry 10(3):305-318.

Campbell, D.T., and J.C. Stanley. 1963. Experimental and QuasiExperimental Designs for Research. Boston: Houghton Mifflin Company.

Campbell, L. 2015. Constructing New York City's urban forest. The politics and governance of the MillionTreesNYC campaign. pp. 242-260. In: L.A. Sandberg, A. Bardekjian, and S. Butt (Eds.). Urban Forests, Trees and Greenspace: A Political Ecology Perspective. Routledge, New York, New York, U.S.

Clark, J.R., N.P. Matheny, G. Cross, and V. Wake. 1997. A model of urban forest sustainability. Journal of Arboriculture 23(1):17-30.

Dale, A., and S. Frank. 2014. The effects of urban warming on herbivore abundance and street tree condition. PLoS ONE 9(7).

Denig, B.R. 2014. Ithaca's Trees: Master Plan, Inventory and Arboricultural Guidelines for the Public Trees of the City of Ithaca, New York. <www.hort.cornell.edu/uhi/outreach/pdfs/IthacasTrees.pdf $>$

Driscoll, A., P. Ries, J. Tilt, and L. Ganio. 2015. Needs and barriers to expanding urban forestry programs: An assessment of community leaders and program managers in the PortlandVancouver metropolitan region. Urban Forestry \& Urban Greening 14(1):48-55.

Dwyer, J.F., E.G. McPherson, H.W. Schroeder, and R.A. Rowntree. 1992. Assessing the benefits and costs of the urban forest. Journal of Arboriculture 18(5):227-227.

Elmendorf, W. 2008. The importance of trees and nature in community: A review of relative literature. Arboriculture \& Urban Forestry 34(3):152-156.

Ferrini, F., and A. Fini. 2011. Sustainable management techniques for trees in the urban areas. Journal of Biodiversity and Ecological Sciences 1(1).

Gaskin, G.J., and J.D. Miller. 1996. Measurement of soil water content using a simplified impedance measuring technique. Journal of Agricultural Engineering Research 63(2):153-59.

Grado, S.C., D.L. Grebner, M.K. Measells, and A.L. Husak. 2006. Status, needs, and knowledge levels of Mississippi's communities relative to urban forestry. Journal of Arboriculture 32(1): 24-32.

Honey-Rosés, J., K. Baylis, and M.I. Ramírez. 2011. A spatially explicit estimate of avoided forest loss. Conservation Biology 25 (5):1032-43.

Jack-Scott, E., M. Piana, B. Troxel, C. Murphy-Dunning, and M.S. Ashton. 2013. Stewardship success: How community group dynamics affect urban street tree survival and growth. Arboriculture \& Urban Forestry 39(4):189-196.

Johnson, J.R., G.R. Johnson, M.H. McDonnough, L.L. Burban, and J.K. Monear. 2010. Tree Owner's Manual. United States Department of Agriculture, Forest Service, Northeastern Area State and Private Forestry. <www.treeownersmanual.info $>$ 
Kenney, W.A., P.J.E. van Wassenaer, and A.L. Satel. 2011. Criteria and indicators for strategic urban forest planning and management. Arboriculture \& Urban Forestry 37(3):108-117.

Kerlinger, F.N., and H.B. Lee. 2000. Foundations of behavioral research. In: Foundations of Behavioral Research, fourth edition. Cengage Learning, Belmont, California, U.S.

Lechner, M. 2011. The estimation of causal effects by difference-indifference methods. Foundations and Trends in Econometrics 4(3):165-224.

Leff, M. (Ed.). 2013. Cities and the Environment special issue: Urban forestry practitioners share all. $<\mathrm{http} / /$ digitalcommons. lmu.edu/cate/vol6/iss1>

Lehman, P.K., and E.S Geller. 2004. Behavior analysis and environmental protection: Accomplishments and potential for more. Behavior and Social Issues 13:13-32.

Loukaitou-Sideris, A., and I. Ehrenfeucht. 2009. Sidewalks: Conflict and Negotiation Over Public Space. MIT Press, Cambridge, Massachusetts, U.S.

Lu, J.W.T., E.S. Svendsen, L.K. Campbell, J. Greenfeld, J. Braden, K L. King, and N. Falxa-Raymond. 2010. Biological, social and urban design factors affecting youth street tree mortality in New York City. Cities and the Environment 3(1):Article 1. <http:// digitalcommons.lmu.edu/cate/vol3/iss1/5>

McKenzie-Mohr, D. 2011. Fostering sustainable behavior: An introduction to community-based social marketing, third edition. New Society, Gabriola Island, British Columbia, Canada.

Mincey, S.K., and J.M. Vogt. 2014. Watering strategy, collective action, and neighborhood planted trees: A case study of Indianapolis, Indiana, U.S. Arboriculture \& Urban Forestry 40(2):84-95.

Moskell, C., and S.B. Allred. 2013. Residents' beliefs about responsibility for the stewardship of park trees and street trees in New York City. Landscape and Urban Planning 120:85-95.

Pataki, D.E., M.M. Carreiro, J. Cherrier, N.E. Grulke, V. Jennings, S. Pincetl, R.V. Pouyat, T.H. Whitlow, and W.C. Zipperer. 2011. Coupling biogeochemical cycles in urban environments: Ecosystem services, green solutions, and misconceptions. Frontiers in Ecology and the Environment 9(1):27-36.

Pattanayak, S.K., S. Wunder, and P.J. Ferraro. 2010. Show me the money: Do payments supply environmental services in developing countries? Review of Environmental Economics and Policy 4(2):254-274.

Pincetl, S., T. Gillespie, D.E. Pataki, S. Saatchi, and J.D. Saphores. 2013. Urban tree planting programs, function, or fashion? Los Angeles and urban tree planting campaigns. GeoJournal 78(3):475-493.

Roman, L.A., and F.N. Scatena. 2011. Street tree survival rates: Meta-analysis of previous studies and application to a field survey in Philadelphia, PA, USA. Urban Forestry \& Urban Greening 10(4):269-274.

Roman, L.A., J.J. Battles, and J.R. McBride. 2014. The balance of planting and mortality in a street tree population. Urban Ecosystems 17:387-404.

Shadish, W.R., T.D. Cook, and D.T. Campbell. 2001. Experimental and Quasi-experimental Designs for Generalized Causal Inference. Houghton Mifflin, Boston, Massachusetts, U.S. 656 pp.

Sklar, F., and R.G. Ames. 1985. Staying alive: Street tree survival in the inner city. Journal of Urban Affairs 7(1):55-66.

Sommer, R., F. Learey, J. Summit, and M. Tirrell. 1994. The social benefits of resident involvement in tree planting. Journal of Arboriculture 20(3):170-175.
Steg, L., and C. Vlek. 2009. Encouraging pro-environmental behavior: An integrative review and research agenda. Journal of Environmental Psychology 29(3):309-317.

Stone, E.A, J. Wu, and R. Alig. 2015. Urban green space and vibrant communities: Exploring the linkage in the Portland-Vancouver area. General Technical Report-Pacific Northwest Research Station, USDA Forest Service, no. PNW-GTR-905.

Summit, J., and R. Sommer. 1998. Urban tree-planting programs: A model for encouraging environmentally protective behavior. Atmospheric Environment 32(1):1-5.

Tetlow, R.M., C.P. Beaman, A.A. Elmualim, and K. Couling. 2014. Simple prompts reduce inadvertent energy consumption from lighting in office buildings. Building and Environment 81:234-242.

Trowbridge, P.J., and N. Bassuk. 2004. Trees in the Urban Landscape: Site Assessment, Design, and Installation. J. Wiley \& Sons, Hoboken, New Jersey, U.S.

Vaske, J.J. 2008. Survey Research and Analysis: Applications in Parks, Recreation and Human Dimensions. Venture Publishing, State College, Pennsylvania, U.S.

Vico, G., R. Revelli, and A. Porporato. 2014. Ecohydrology of street trees: Design and irrigation requirements for sustainable water use. Ecohydrology 7:508-523.

Whitlow, T.H., and N.L Bassuk. 1988. Ecophysiology of urban trees and their management: The North American experience. HortScience 23(2):542-546.

Whitlow, T.H., N.L. Bassuk, and D.L. Reichert. 1992. A three-year study of water relations of urban street trees. The Journal of Applied Ecology 29(2):436

Young, R.F. 2011. Planting the living city. Journal of the American Planning Association 77(4):368-381.

Young, R.F., and E.G. McPherson. 2013. Governing metropolitan green infrastructure in the United States. Landscape and Urban Planning 109:67-75.

Zimmerman, M.A. 2006. Empowerment theory: Psychological, organizational, and community levels of analysis. pp. 43-63. In: J. Rappaport and E. Seidman (Eds.). Handbook of Community Psychology. Kluwer Academic Publishers, New York, New York, U.S.

\author{
Christine Moskell, Ph.D. (corresponding author) \\ Human Dimensions Research Unit \\ Department of Natural Resources \\ 111 A Fernow Hall \\ Cornell University \\ Ithaca, New York 14853, U.S. \\ csm94@cornell.edu
}

Nina Bassuk, Ph.D.

Urban Horticulture Institute

School of Integrative Plant Science - Horticulture Section

33 Plant Science Building

Cornell University

Ithaca, New York 14853, U.S.

nlb2@cornell.edu 
Shorna Allred, Ph.D.

Human Dimensions Research Unit

Department of Natural Resources

102 Fernow Hall

Cornell University

Ithaca, New York 14853, U.S.

srb237@cornell.edu

Pat McRae

Urban Horticulture Institute

School of Integrative Plant Science - Horticulture Section

147B Plant Science Building

Cornell University

Ithaca, New York 14853, U.S.

pfm25@cornell.edu

Résumé. Les arbres d'alignement génèrent de nombreux avantages environnementaux, communautaires et de santé, mais les programmes municipaux de foresterie urbaine manquent souvent de ressources publiques pour entretenir adéquatement les arbres, particulièrement durant la période suivant immédiatement la plantation. Larrosage des arbres pendant les trois premières années suivant la plantation est essentiel à la survie des arbres. Un modèle quasi expérimental a été utilisé pour valider si une sensibilisation structurée sur le terrain pouvait influencer les pratiques habituelles des résidents concernant l'arrosage des arbres d'alignement et si leur pratique d'arrosage améliorait l'humidité du sol, un résultat important pour la croissance des arbres. Les résidents retenus aux fins de sensibilisation du groupe de traitement ont tous reçu par la poste, de la documentation éducative concernant l'arrosage de l'arbre municipal, tandis que ceux du groupe témoin n'ont reçu aucune documentation. Les données d'humidité du sol ont été recueillies chaque semaine sur tous les arbres tout au long de la saison de croissance (de mai à septembre 2012) et utilisées comme indicateur du comportement des résidents quant à l’arrosage. Les résultats indiquent que les envois postaux ont eu un impact positif sur le comportement des résidents concernant l'arrosage, mais que cet impact a diminué au fil du temps. Bien que l'impact des envois postaux sur l'humidité du sol n'ait pas été statistiquement significatif, l'évaluation de l'activité de sensibilisation revêt a une signification pratique pour les futurs efforts éducationnels afin d'amener les résidents à arroser les arbres d'alignement.

Zusammenfassung. Straßenbäume liefern zahlreiche Vorteile für Umwelt, Gemeinschaft und Gesundheit, aber kommunale Forstprogramme entbehren oft öffentlicher Mittel, um Bäume angemessen zu pflegen, besonders in der Zeit direkt nach der Pflanzung. Das Wässern von Bäumen in den ersten drei Jahren nach der Pflanzung ist kritisch für das Überleben. Ein sozusagen experimentelles Design wurde hier verwendet, um zu testen, ob eine öffentliche Intervention das Verhalten der Anwohner bezüglich Straßenbaumbewässerung beeinflussen kann und ob das Bewässerungsverhalten die Bodenfeuchte als wichtige Voraussetzung für gesundes Baumwachstum verbessert. Die Anwohner in der Adressenliste für eine solche Behandlung erhielten Informationsmaterial über Bewässerung, während die Kontrollgruppe nichts erhielt. Die BodenfeuchteDaten wurden für jeden Baum innerhalb der Vegetationsperiode (Mai-September) wöchentlich gesammelt und stellvertretend für das Bewässerungsverhalten der Anwohner betrachtet. Die Ergebnisse zeigten, dass die Postkarte einen positiven Einfluss auf das Gießverhalten der Anwohner hatte, aber der Einfluss verlor sich mit der Zeit. Währen der Einfluss der Postkarte auf den Boden- feuchtegrad statistisch nicht relevant war, hatte die Bewertung der öffentlichen Intervention eine praktische Bedeutung für zukünftige Informationsbemühungen, um die Anwohner zur Bewässerung von Straßenbäumen anzuregen.

Resumen. Los árboles urbanos proporcionan numerosos beneficios ambientales, comunitarios y de salud, pero los programas municipales a menudo carecen de los recursos públicos para mantener adecuadamente los árboles, sobre todo en el momento inmediatamente después de la plantación. El riego de árboles en los tres primeros años después de la plantación es crítico para la supervivencia de los árboles. Se utilizó un diseño cuasi-experimental para probar el comportamiento de riego del árbol al alcance de los residentes y si ese riego mejoró la humedad del suelo, un resultado importante para el crecimiento de los árboles. En las direcciones de correo los residentes recibieron materiales educativos sobre el riego, mientras que el grupo de control no recibió materiales educativos. Se recogieron datos de humedad del suelo semanalmente en todos los árboles a lo largo de la temporada de crecimiento (mayoseptiembre de 2012) y esto se utilizó como un indicador de la conducta de los residentes. Los resultados indican que las tarjetas postales tuvieron un impacto positivo en el comportamiento de los residentes para el riego, pero el impacto disminuyó con el tiempo. Si bien el impacto de las postales no fue estadísticamente significativo en la humedad del suelo, la evaluación de la intervención tiene una importancia práctica para los futuros esfuerzos educativos para involucrar a los residentes en el riego de los árboles urbanos. 